\title{
THE ENVIRONMENTAL TECHNOLOGIES ACCEPTANCE (ETA) PROGRAM
}

\author{
Semiannual Report \\ for the period April 1 through September 30, 2001 \\ (including quarterly report for the period July 1 -September 30, 2001) \\ Prepared for: \\ AAD Document Control \\ National Energy Technology Laboratory \\ U.S. Department of Energy \\ PO Box 10940, MS 921-143 \\ Pittsburgh, PA 15236-0940 \\ Cooperative Agreement No.: DE-FC26-00NT40840 \\ Performance Monitor: Edgar Klunder
}

Prepared by:

Christina B. Behr-Andres

Energy \& Environmental Research Center

University of North Dakota

PO Box 9018

Grand Forks, ND 58202-9018

October 2001 


\section{DISCLAIMER}

This report was prepared as an account of work sponsored by an agency of the United States Government. Neither the United States Government, nor any agency thereof, nor any of their employees makes any warranty, express or implied, or assumes any legal liability or responsibility for the accuracy, completeness, or usefulness of any information, apparatus, product, or process disclosed or represents that its use would not infringe privately owned rights. Reference herein to any specific commercial product, process, or service by trade name, trademark, manufacturer, or otherwise does not necessarily constitute or imply its endorsement, recommendation, or favoring by the United States Government or any agency thereof. The views and opinions of authors expressed herein do not necessarily state or reflect those of the United States Government or any agency thereof.

\section{EERC DISCLAIMER}

LEGAL NOTICE This research report was prepared by the Energy \& Environmental Research Center (EERC), an agency of the University of North Dakota, as an account of work sponsored by the U.S. Department of Energy (DOE). Because of the research nature of the work performed, neither the EERC nor any of its employees makes any warranty, express or implied, or assumes any legal liability or responsibility for the accuracy, completeness, or usefulness of any information, apparatus, product, or process disclosed, or represents that its use would not infringe privately owned rights. Reference herein to any specific commercial product, process, or service by trade name, trademark, manufacturer, or otherwise does not necessarily constitute or imply its endorsement or recommendation by the EERC.

This report is available to the public from the National Technical Information Service, U.S. Department of Commerce, 5285 Port Royal Road, Springfield, VA 22161; phone orders accepted at (703) $487-4650$.

\section{ACKNOWLEDGMENT}

This report was prepared with the support of the DOE National Energy Technology Laboratory Cooperative Agreement No. DE-FC21-94MC31388. However, any opinions, findings, conclusions, or recommendations expressed herein are those of the authors(s) and do not necessarily reflect the views of DOE. 


\section{TABLE OF CONTENTS}

LIST OF FIGURES $\ldots \ldots \ldots \ldots \ldots \ldots \ldots \ldots \ldots \ldots \ldots \ldots \ldots \ldots \ldots \ldots$

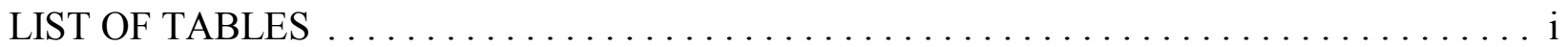

INTRODUCTION $\ldots \ldots \ldots \ldots \ldots \ldots \ldots \ldots \ldots \ldots \ldots \ldots \ldots \ldots \ldots \ldots \ldots \ldots$

ACCOMPLISHMENTS $\ldots \ldots \ldots \ldots \ldots \ldots \ldots \ldots \ldots \ldots \ldots \ldots \ldots \ldots \ldots$

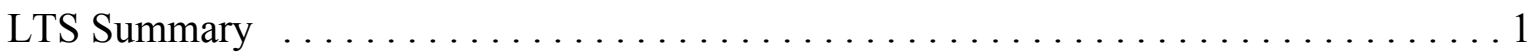

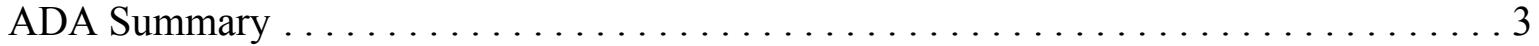

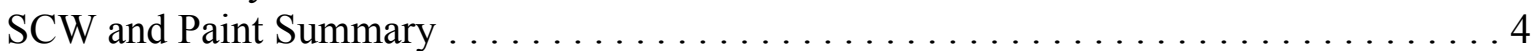

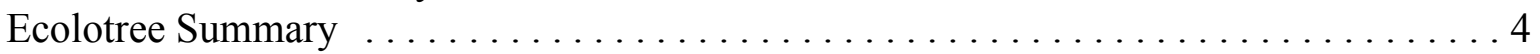

\section{LIST OF FIGURES}

1 Effect of subcritical water temperature on degradation of PCBs in paint sample and

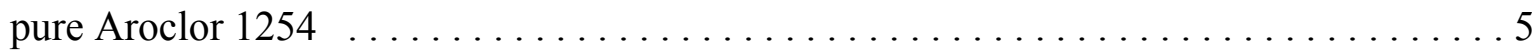

\section{LIST OF TABLES}

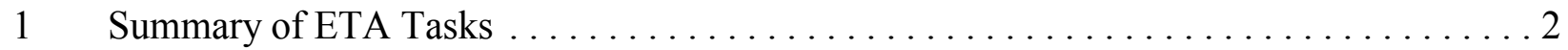




\section{THE ENVIRONMENTAL TECHNOLOGIES ACCEPTANCE PROGRAM}

\section{INTRODUCTION}

The objective of the Environmental Technologies Acceptance (ETA) Program at the Energy \& Environmental Research Center (EERC) is to advance the development, commercial acceptance, and timely deployment of selected private sector technologies for the cleanup of sites in the nuclear defense complex as well as the greater market. As a result of contract changes approved by National Energy Technology Laboratory (NETL) representatives to incorporate activities previously conducted under another NETL agreement, there are now an additional task and an expansion of activities within the stated scope of work of the ETA program. As shown in Table 1, this cooperative agreement, funded by NETL (No. DE-FC26-00NT40840), consists of four tasks: Technology Selection, Technology Development, Technology Verification, and System Engineering. As currently conceived, ETA will address the needs of as many technologies as appropriate under its current 3-year term. There are currently four technical subtasks: Long-Term Stewardship Initiative at the Mound Plant Site; Photocatalysis of Mercury-Contaminated Water; Subcritical Water Treatment of PCB and Metal-Contaminated Paint Waste; and Vegetative Covers for Low-Level Waste Repositories. This report covers activities during the second six months of the three-year ETA program.

\section{ACCOMPLISHMENTS}

Activities in the second six months of this contract include the following:

- Regular monthly program meetings were held to track project progress.

- Project work plans for each technical subtask were revised according to comments of the project's industrial partner and NETL personnel and were approved by NETL personnel.

- The program's continuation application was prepared and submitted, including modifications to expand activities within the scope of Task 1 and the addition of Task 4 .

\section{LTS Summary}

EERC personnel participated in the Fourth Annual Long-Term Stewardship (LTS) Workshop in Grand Junction, Colorado, July 30 - August 2, 2001. Contacts were made with members of U.S. Department of Energy (DOE) Mound, Ohio, BWXT, Ohio, and the Miamisburg Mound Community Improvement Corporation (MMCIC). We participated in numerous breakout sessions, discussing issues related to LTS. 
Table 1. Summary of ETA Tasks

\begin{tabular}{|c|c|}
\hline Task Name & Task Summary \\
\hline \multicolumn{2}{|l|}{1 - Technology Selection } \\
\hline $\begin{array}{l}1.1 \text { - Determination of Key } \\
\text { Problems to Be Addressed }\end{array}$ & $\begin{array}{l}\text { Using the EM Focus Area multiyear program plans, technologies that meet } \\
\text { key needs will be matched with EERC areas of expertise. Resulting } \\
\text { technologies will be prioritized, and relationships will be developed with } \\
\text { Focus Area personnel and end users. A short list of site needs, industry } \\
\text { partners, and technologies will be prepared, and the EERC will facilitate } \\
\text { discussion concerning technology selection for ETA activities. }\end{array}$ \\
\hline $1.2-$ Selection of Technologies & $\begin{array}{l}\text { EERC personnel will assess the merits of OST-developed technologies } \\
\text { addressing needs identified under Task } 1.1 \text { and will assess the merits of other } \\
\text { candidate technologies. Results will be submitted to the advisory group to } \\
\text { select technologies for the ETA program. }\end{array}$ \\
\hline $\begin{array}{l}1.3 \text { - Development of a } \\
\text { Technology Assistance Work } \\
\text { Plan }\end{array}$ & $\begin{array}{l}\text { The EERC will develop detailed work plans based on input from end users, } \\
\text { Focus Area personnel, and technology developers that address specific issues } \\
\text { for the technologies selected under Task 1.2. }\end{array}$ \\
\hline \multicolumn{2}{|l|}{2 - Technology Development } \\
\hline $\begin{array}{l}2.1 \text { - Performance of } \\
\text { Experiments }\end{array}$ & $\begin{array}{l}\text { Experiments and/or nonexperimental development work intended to resolve } \\
\text { technical problems and accelerate technology development. Scope of work is } \\
\text { technology-dependent. }\end{array}$ \\
\hline $\begin{array}{l}2.2-\text { Evaluation and Reporting } \\
\text { of Results }\end{array}$ & $\begin{array}{l}\text { Results will be reduced, analyzed, and communicated through a } \\
\text { comprehensive report. }\end{array}$ \\
\hline \multicolumn{2}{|l|}{3 - Technology Verification } \\
\hline 3.1 - Verification Setup & $\begin{array}{l}\text { The type of verification will be determined and the appropriate preliminary } \\
\text { activities performed to facilitate successful testing. }\end{array}$ \\
\hline 3.2 - Verification Testing & Verification testing and associated analytical work. \\
\hline $\begin{array}{l}\text { 3.3 Evaluation and Reporting of } \\
\text { Results }\end{array}$ & $\begin{array}{l}\text { The results of verification activities will be described in detail in a } \\
\text { comprehensive technology development report that will serve as an } \\
\text { Innovative Technology Report Summary (ITRS). }\end{array}$ \\
\hline 4 - Systems Engineering & $\begin{array}{l}\text { Decision-making tools will be developed to facilitate efficient and direct } \\
\text { interaction between the technology users and the technology developers to } \\
\text { advance the development, commercial acceptance, and deployment of new } \\
\text { technologies complexwide. }\end{array}$ \\
\hline
\end{tabular}

BWXT, Ohio, requested that the EERC provide a complexwide LTS needs assessment for use as a basis for BWXT's own needs assessment. A draft work plan was submitted to Sue Smiley, LTS head at Mound, and to Don Krause, Ted Quale, and Joyce Massie of BWTX, Ohio. We are currently in the process of gathering and inputting LTS needs into a database similar to the Deactivation and Decommissioning Information System (DDIS) database created for DDFA. 
Information was gathered and contacts were made while attending the Albuquerque Needs Workshop held in Santa Fe, New Mexico, August 20-22, 2001. Roger Mayes, LTS representative at Idaho National Engineering and Environmental Laboratory (INEEL), provided us with critical information regarding LTS advancements made by INEEL in the construction of complexwide needs statements.

As part of the Mound LTSI Technology Team, we attended the kickoff meeting at the Mound site in Dayton, Ohio, September 11-12, 2001. Each team member provided an introductory presentation outlining expertise and capabilities. Three immediate needs were discussed at this meeting. Monitoring technologies will need to be identified to enforce the following restrictions:

1. No soil may be removed from the site without approval of the state.

2. No domestic groundwater well installation on-site.

3. Buildings and property may be used solely for industrial purposes.

Team members meet biweekly via teleconference to discuss progress related to each team member's assigned tasks.

\section{ADA Summary}

Samples of $\mathrm{TiO}_{2}$ photocatalytic sorbent materials were acquired from ADA Technologies and subjected to characterization analyses. These samples consisted of the following:

- Raw Degussa P25

- Agglomerated P25

- Agglomerated P25 with a binder added

- Agglomerated P25 with binder and etched with $4 \mathrm{M} \mathrm{HNO}_{3}$

- Agglomerated P25 with binder and etched with $4 \mathrm{M} \mathrm{NaOH}$

- P25 with a dispersed noble metal

- Agglomerated P25 with binder and dispersed noble metal

Each of these samples was analyzed using x-ray diffraction (XRD) and scanning electron microscopy (SEM) to determine catalyst crystallography, particle morphology, and surface composition. All the samples were found to be well crystallized, and the major form was anatase. The major difference between the agglomerated samples was particle size. All samples appeared to be highly porous.

A laboratory-scale photocatalysis reactor system was designed and fabricated. The system will be used to verify previous ADA test results as well as to attempt to optimize sorbent utilization using a different reactor configuration than previously tested. The single-column reactor is fabricated from borosilicate glass with a single, centrally located $40-\mathrm{W}$ black light. The overall operating volume of the reactor is approximately 20 liters ( 5 gal). The system employs a recycle loop to control required residence times as opposed to plug flow through multiple 
columns. Additional sorbent samples will be prepared by ADA for use in performance verification testing.

\section{Subcritical Water and Paint Summary}

Since the composition of polychlorinated biphenyl (PCB) mixtures differs, we initially determined the PCB composition in paint samples obtained from CMS Energy. The abundance of individual PCB congeners was similar to the commercial mixture Aroclor 1254. The concentrations of individual PCBs were in the range of $1-40 \mathrm{ppm}$, corresponding to a total PCB concentration of ca. $130 \mathrm{ppm}$.

Based on the preliminary experiments with the individual congener, hexachlorobiphenyl (PCB 155), degradation experiments were performed in subcritical water at two temperatures$300^{\circ}$ and $350^{\circ} \mathrm{C}$ - for 1 hour. To be able to observe the effect of the paint sample matrix, additional experiments with pure Aroclor 1254 were performed. Both the effect of temperature and sample matrix are shown in Figure 1. The data in Figure 1 are based on the abundance of homologous groups of PCBs in paint and standard Aroclor 1254 prior to and after degradation. At $300^{\circ} \mathrm{C}$, the total mass of PCBs did not change, but Figure 1 shows significant dechlorination of hexa- and heptachlorinated biphenyls to tetrachlorinated biphenyls. The increase in extent of dechlorination is even more pronounced at $350^{\circ} \mathrm{C}$, where the total content of PCBs decreased to $55 \pm 6 \%$. In contrast to the degradation of PCBs in paint, no significant degradation was observed for pure Aroclor 1254 (Fig. 1). Consequently, the extent of degradation can be attributed not only to the temperature of subcritical water, but also to additives which are present in the paint.

Future studies will include the possibility that paint additives (e.g., lead) enhance PCB dechlorination.

\section{Ecolotree Summary}

This project consists of the design of a vegetative cover for a low-level waste (LLW) repository at the Savannah River Site (SRS). The purpose of the cover would be to eliminate infiltration of moisture into the LLW layer, thus minimizing leaching of hazardous materials into the surrounding soil or aquifer. The EERC is working with Ecolotree, Inc., of Iowa City, Iowa, to design the vegetative cover for SRS. Incorporated in 1990, Ecolotree is the oldest and most experienced company in the United States that specializes in the design and installation of vegetative covers for landfills and other waste repositories.

A project work plan was prepared that calls for 1) an identification of vegetative cover needs in terms of vegetation type, climate, site-specific geology, and LLW characteristics; 2) collection of data needed for design of the cover; 3 ) design and modeling of the vegetative cover; and 4) performance of preliminary economic and market evaluations for the application of vegetative covers to LLW or hazardous waste repositories. 

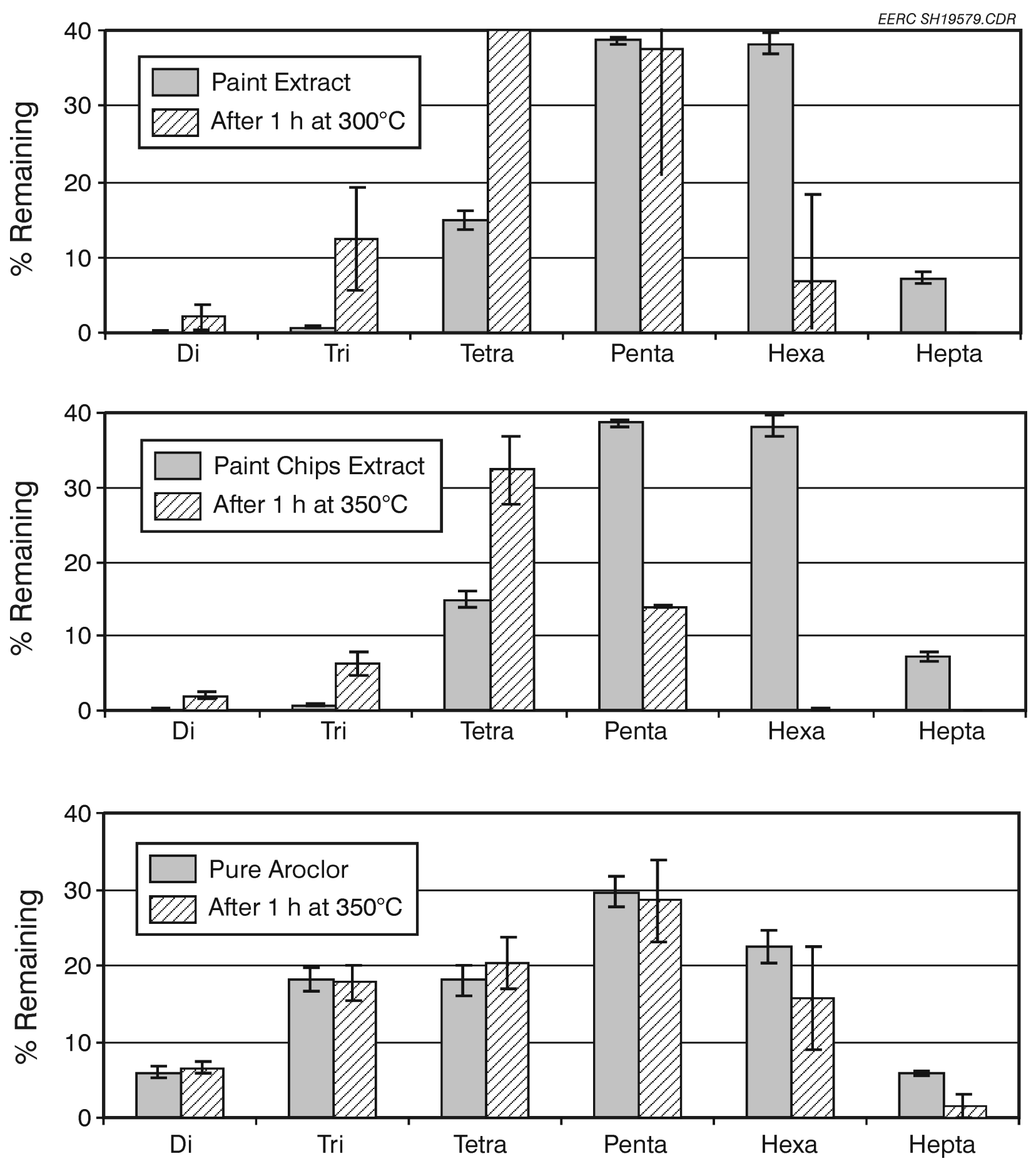

Figure 1. Effect of subcritical water temperature on degradation of PCBs in paint sample and pure Aroclor 1254. 
Following approval of the work plan by the Contracting Officer's Representative, project personnel used literature and Internet searches to identify:

- The vegetative cover needs (as well as other related needs) over the EM complex.

- The technical responses to the various EM vegetative cover needs.

- Publicly available information about the characteristics of LLW.

- The requirements specific to a vegetative cover at SRS (such as climate and geology).

- Indigenous plants that are found in South Carolina and might be candidates for inclusion in the vegetative cover.

Preparations were made for modeling the infiltration and leaching from the vegetative cover by purchasing Hydrus-2D (Version 2.02) modeling software from the International Ground Water Modeling Center. This software will be used during the design of the vegetative cover as well as to monitor its performance should it be installed at the end of this project. The computer capabilities of project personnel were upgraded to facilitate use of the rather extensive modeling software. Plans were made for Bethany Bolles to attend a short course on September 15 and 16, 2001, to learn to use Hydrus-2D. The trip was canceled in the wake of the September 11, 2001, terrorist attacks.

Communication with various researchers at SRS was initiated in an effort to determine the specific needs of a vegetative cover at the site and to involve them as end users. Contacts were made with Michael Serrato, Robert Blundy, and Daniel Kaplan. Information that was exchanged included background information about the ETA program, Ecolotree's capabilities and accomplishments, specific information regarding the project including the work plan, and the desire to set up a meeting at SRS to review the project and determine the best way in which to proceed. A visit to SRS has not taken place because of the tightened security at the site, although planning for such a meeting is continuing. A slide presentation has been prepared in anticipation of the meeting.

At the request of SRS researchers, the protocol for removal of a vegetative cover should it not perform as designed and expected is being formulated. Actual installation of the vegetative cover is beyond the scope of this project but such a contingency plan is an important facet of a complete work plan.

Travel arrangements were made for Melanie Jensen and Bethany Bolles to visit Ecolotree's headquarters on October 16 and 17, 2001, to discuss the project, to visit some of its test sites, and to learn more about the use of Hydrus-2D in the design and monitoring of vegetative covers. 